Вісник Львівського університету. Серія філос.-політолог. студіі. 2019. Випуск 26, с. 95-100

Visnuk of the Lviv University. Series Philos.-Political Studies. Issue 26, p. 95-100

УДК 227.87

DOI https://doi.org/10.30970/2307-1664.2019.26.12

\title{
THE BIBLICAL CONCEPT OF GOD'S REST IN THE LIGHT OF THE EPISTLE TO THE HEBREWS
}

\author{
Alexander Shumilin \\ Bishkek Bible College \\ Tverskaya str., 42, 720080, Bishkek, Kyrgyzstan
}

The article is devoted to the study of the theological concept of God's rest in the context of 3-4 chapters of the book of Hebrews. The goal is to show what meaning the author of the Epistle puts into this concept, and also to understand why the author addresses this topic and how this concept fits into the context of the entire Epistle, as well as the entire Bible. Particular attention is paid to the study of the key phrase "Let us labour therefore to enter into that rest".

An analysis of sources devoted to this topic. It is shown that there are different opinions regarding "rest". Some authors claim that God's peace is associated with eschatological events and is acquired at the end of a Christian's life in heaven. Others believe that rest is the return of the lost unity of man with God, it is the peace in God given to us through Christ. Still others believe that peace is a testimony of conscience about the forgiveness of sins and peace in the Father's house in Heaven. Fourth see peace as a combination of salvation in Christ (confidence in salvation) with the future world in heaven. Fifths see peace as being in Christ, and its loss as a result of the doubts of believers. What causes a different understanding of God's world? Are there any other possible interpretations? The answer to these questions is one of the goals of this study.

For research in the framework of this article, the hermeneutic-exegetical method was used. A brief introduction to the Epistle is made, the estimated date of writing of the Epistle is given, the main theme is identified, the purpose of the Epistle, and the historical context is indicated. An etymological analysis of words and literary analysis of the text are carried out. It is shown how the author of the message uses a typology to achieve his goal.

It is shown that the message in the style of the sermon was written either during the period of persecution of Christians, or in the preceding time. Apparently, difficult times affected the faith of members of the community. Some of them have cooled, some have disappeared, some have fallen into sin, some may have returned to the Jewish system of values again. In the Epistle, the author tries again to draw the attention of community members to Christ. He shows the superiority of Christ over the prophets, Angels, Abraham, Moses, Aaron, the Old Testament priestly system of service. The author shows the divinity of Jesus Christ, talks about the purposelessness, meaninglessness and even the dangers of life without Him and calls for a return to faith in Him.

In his hermeneutic-exegetical study of the Old Testament narratives in Ps. 95:8-11 and Genesis 2:2, the author of the Epistle shows that God's true rest for believers of all times is not even a promised land and protection from enemies, but the restoration of broken relationship with God, union with Him and abiding in Christ. Ultimately, peace is an eternal fellowship with God in the kingdom of heaven.

The theme of God's peace is relevant and in our time is of great importance for all Christians and especially for those who are in persecution, difficulties, as well as those who are spiritually weak, cooled and in danger of falling away from Christ.

Key words: God's rest in Hebrews, Hebrews 3-4, warnings of falling away in the book of Hebrews, enter God's rest.

(C) A. Shumilin, 2019 
How do scholars of Scripture understand the 3rd and 4th chapters of the Hebrews, in which the theme of God's rest is central? How do the interpreters understand the word "rest", which is the key in this passage and sounds there 9 times? How do they understand the key phrase "to enter into rest", which occurs 8 times, and the text "Let us labour therefore to enter into that rest” $(4: 7,11)$ ?

Almost all scholars of the book of Hebrews are united in that the people of Israel understood the "world" as a promised land and protection from enemies (Deut. 12: 9-12; Heb. 3: 11, 18-19). Not everyone is united in what sense God Himself originally put into the word "rest" and the phrase "my world", how should Israel understand them and how do New Testament believers understand this? Some authors [1, p. 1767-1768; 2, p. 804; 3, p. 28; 4, p. 73] claim that God's peace is associated with eschatological events and is achieved at the end of a Christian's life in heaven. Others [5, p. 448] believe that the world is the return of the lost unity of man with God, this is the rest in God given to us through Christ. Still others believe that peace is a testimony of conscience about the forgiveness of sins and peace in the Heavenly house of the Father [6, p. 1329-1330]. Fourth see the world as a combination of salvation in Christ (confidence in salvation) with the future world in heaven [7, p. 41; 8, p. 161-162]. We find approximately the same opinion in [9, p. 674]. Fifth [10, p. 498] see the world in Christ and its loss - as a result of the doubts of believers (someone negatively influenced them, saying that the day of the Lord has already begun). Which of the following interpretations is closer to context? Are there any other opinions on this? Answers to these questions are one of the goals of this study.

We carry out hermeneutic-exegetical studies. In the beginning we will make a small introduction, pay attention to the historical context and structure of the message, and define the context of passage 3:7-4:12.

The Epistle to the Hebrews is mentioned in the Epistle of Clement of Rome to the Corinthians in 95 CE. [11, p. 415; 12, p. 514], and therefore it could not be written later than this date. The Epistle deals with the temple system of service. This means that the message is most likely written before the destruction of the temple, i.e. until 70 AD. Mention of Timothy at 13:23, who died for faith in $81 \mathrm{AD}$ also testifies in favor of an earlier date of writing of the Message.

Judging by some passages of the message $(6: 13-20 ; 10: 32-37 ; 12: 4-11)$, the community to which this message was addressed was persecuted or was on the threshold of it [13, p. 361].

It is possible that as a result of the persecution, some members of the community refused to believe in Christ and returned to the Jewish system of values [14, p. 860], some took the path of $\sin ($ see $2: 1-4 ; 3-4 ; 5: 11-6: 12 ; 10: 26-31 ; 12: 4-17)$.

The features of the message include the absence of an introductory greeting and a narrative style of writing. "Oratory intonations and remarks such as "for the time would fail me to tell of..." (Heb. 11:32), apparently, should mean oral preaching. However, the statement: "for I have written a letter unto you in few words" (Heb. 13:22) - forces us to conclude that this is still a message, although it was written in the style of a sermon" [11, p. 416].

The Epistle was addressed to the church $(10: 32 ; 13: 7,17)$ and it's purpose is to show the greatness of Jesus Christ, to warn members of the community from falling away, and possibly return the apostates on the path of faith. In his message the author shows the superiority of Christ and his values over Judaism and its system of values. Jesus is higher than the prophets $(1: 1-2)$, higher than the Angels (chap. 1-2). His Priesthood is higher than the earthly (2:17-8: 6). He is the Intercessor of the best Testament (chapters 8-9). He is the Best Sacrifice (chap. 10). He is the Son of God (1:1-14; 3:1-6; 7:1-11). He needs to be followed. The promises for His followers are far more than the promises given to the followers of Moses. 
The context for passage 3:7-4:11, which sets forth the concept of God's rest, is text 2:17$5: 10$. Verse $3: 7$ is grammatically related to the previous text $3: 1-6$, which refers to the need for readers of the Epistle to understand the high priestly position of Christ, Text 3:1-6, in turn, goes in the same conjunction with 2:17-18, in which begins the narrative of the High Priesthood of Christ. Verse 4:11 is grammatically related (see conjunctions) with $4: 14$, and that one is logically with $4: 15-5: 10$.

Text 2:17 - 5:10 is built in the form of chiasm.

A1. The High Priesthood of Christ must be understood (2:17-3: 6)

B1. Many Israelites did not enter rest (3:7-19)

B2. Some Christians need to get into rest $(4: 1-11)$

A2. Some Christians must turn to the High Priest (4:12-5:10)

Verses 2:17-3:6 speak of Jesus Christ as the High Priest, who understands man (there are the Christians in Hebrews) in his temptations, since He himself was in human flesh and went through temptations. The same verses speak of the fidelity of this high priest, in particular of his willingness to help at all times. Moses, as a minister, was faithful in the task entrusted, much less Jesus, as the Son of God, is faithful in the ministry of the Intercessor entrusted to him by God the Father.

Verses 3:7-19 speak of the "rest" that God promised to Israel, and why about many of these people did not enter this rest. "They shall not enter into my rest" is the oath promise of God. The reason for this was such sins as: "hardening of the heart, unbelief, grumble, deceit, etc., as well as disobedience to Moses as an earthly intercessor.

Verses 4: 1-11 tell of "rest" for the people of God, for the New Testament believers. The words of this passage, urging the sinner to enter into peace, should be especially heeded by those who are in sin, since sin shares a person with God (Isa. 59:1-2; Rom. 6:23).

The main point of passage 4:12-5: 10 is to hasten with repentance to Jesus, as High Priest, to those who are in a state of sin. Jesus will understand everything (5:1-3). It is important not to be late $(4: 16)$.

Text 2: 17-5: 10, built in the form of chiasm, shows that finding peace is connected with Jesus Christ as the High Priest (3:1). This is in good agreement with OT's idea of finding peace with God and deliverance from defeat (perdition) through the intercession of the High Priest. In Numb.16:46-48 we read: "And Moses said unto Aaron, Take a censer, and put fire therein from off the altar, and put on incense, and go quickly unto the congregation, and make an atonement for them: for there is wrath gone out from the LORD; the plague is begun. And Aaron took as Moses commanded, and ran into the midst of the congregation; and, behold, the plague was begun among the people: and he put on incense, and made an atonement for the people. And he stood between the dead and the living; and the plague was stayed". Text 2:17-5:10 applies only to the people of God. In the Old Testament, this is Israel $(3: 9,16-19)$. In the New Testament, this is the Church $(3: 1,12)$. We read in $3: 1$ "Wherefore, holy brethren, partakers of the heavenly calling, consider the Apostle and High Priest of our profession, Christ Jesus" and at 3:12 "Take heed, brethren, lest there be in any of you an evil heart of unbelief, in departing from the living God". The text refers to the people of God, the disobedient God. The passage contains a whole list of the sins of Israel, which can also be manifested in the life of New Testament believers. Moreover, these sins are not only visible, but also invisible. God, as in an x-ray, sees the whole inside of a person (4:12-13).

Having carried out a structural and partially literary analysis of the passage, we pay attention to the phrase "My rest". What Israel should understand by it, and what the Church should understand. 
The first meaning of these words is for Israel the promised land, a safe stay in it and protection from enemies: "For ye are not as yet come to the rest and to the inheritance, which the LORD your God giveth you. But [when] ye go over Jordan, and dwell in the land which the LORD your God giveth you to inherit, and [when] he giveth you rest from all your enemies round about, so that ye dwell in safety; Then there shall be a place which the LORD your God shall choose to cause his name to dwell there; thither shall ye bring all that I command you; your burnt offerings, and your sacrifices, your tithes, and the heave offering of your hand, and all your choice vows which ye vow unto the LORD" (Deut.12:9-11).

Obviously, the above meaning of this phrase is not the only one. In 4:8-9 we read, "For if Jesus [Joshua] had given them peace, then there would have been no mention of another day. Therefore, the Sabbath remains for the people of God". As follows from Josh.1:13 and 11:23 Israel entered the promised land. God reassured him from his enemies. Does peace seem to be found? But no. The Psalmist David, half a millennium after Israel left Egypt and settled in the promised land, writes: "Come, bow and come down, kneel before the Lord our Creator; for He is our God, and we are the people of His flock and the sheep of His hand. Oh, if you would now listen to His voice: "O come, let us worship and bow down: let us kneel before the LORD our maker. For he [is] our God; and we [are] the people of his pasture, and the sheep of his hand. To day, if ye will hear his voice, Harden not your heart, as in the provocation, [and] as [in] the day of temptation in the wilderness: When your fathers tempted me, proved me, and saw my work. Forty years long was I grieved with [this] generation, and said, It [is] a people that do err in their heart, and they have not known my ways: Unto whom I sware in my wrath that they should not enter into my rest" (Ps.95:6-11). The author of Hebrews refers to this text (3:7-19). The people of Israel are already in the promised land, but not yet at peace.

David calls upon the disobedient Israel of his time, Israel living in the promised land to turn to God and worship Him (Ps. 95:1-6). The author of the book of Hebrews, even a thousand years after David, with the same warning ("they will not enter into My rest") addresses the New Testament believers. At that time, Israel was still in the promised land. This warning also sounds today to all Christians of our times. What then should be understood by God's rest? The answer can be obtained by analyzing the texts, first 4:3-4, and then 4:1-16.

Let us see on the text 4:3-4. In it, the author of the Epistle refers to Genesis 2:2, "And by the seventh day God completed His work that He did, and rested on the seventh day from all His work that He did". What is the meaning of this verse? God has calmed down from all His work. Some scholars [15, p. 34-35] are using v.4:10 directly to Christ. He, as a Pioneer, also entered into rest after His dead. When will a Christian calm down of all his work? At the end of his earthly journey (Ps.89: 9-10; Rev.14: 13). Therefore, the second meaning of God's rest is peace in God and life with God at the end of the path of life. Thus, those interpreters are right who, by God's peace, mean the kingdom of heaven. In this context, we should understand Hebrews 4:9.

But, obviously, this interpretation is not the last. The author of the Epistle writes, "For we which have believed do enter into rest, as he said, As I have sworn in my wrath, if they shall enter into my rest: although the works were finished from the foundation of the world" (4:3). Let us pay attention to the word "enter" (ei'serco/meya - praes. Ind. Med.). "Although such form of the word can be interpreted as futuristic, better to understand it as an expression of the current fact ... it can express the idea: "we are already entering" [16, p. 802-803]. One who believed in Christ immediately entered into "God's rest" (4: 3). If this is so, if, having accepted Jesus, the believers went into the rest of God, then why do some of them are called to enter it? There is only one answer (based on the context of the passage 3:7-4:11): sin deprives the Christian of rest (leads out of this rest). The biblical context attests to this (Rom. 6:23; 1Jn. 3:20). Sin devides a person with God. 
The wages of sin is death (spiritual death sharing a person with God). Therefore, the God's rest is peace with God. Having peace with God already on earth, a Christian by faith abides in heavenly rest (Eph. 2: 4-6). Understanding this, the psalmist David says, "Only in God is my soul calmed down: my salvation is from him" (Ps. 61:2). Only in Christ this rest can be found (Jer.6:16; Math.11:29).

To summarize the research, we can say: God's peace is a state of peace with God, which is obtained as a result of repentance and is supported by faith and a righteous life. Peace for a Christian is not a promised land. Moses did not enter the promised land. However, the apostles saw him with Jesus on Mount Transfiguration much later than his death (Math.17:1-3). By faith, he entered into God's rest, remained in it and remains in it. In the context of the whole Epistle to the Hebrews, the phrase "Let us labour therefore to enter into that rest" refers to those who, that, in a result of sin, have lost peace with God and who need to be reconciled with their Creator.

\section{References}

1. Славянский Библейский Комментарий. / Редкол.: С. Санников (гл. редактор). Москва : ЕААА, Библейская Лига, 2016. 1840 с.

2. Словарь Библейских Образов. / Под общей ред. Лиланда Райкена, Джеймса Уилхойта, Тремпера Лонгмана III. Санкт-Петербург : Библия для всех», 2016.

3. DeSilva, David Arthur. Entering God's Rest: Eschatology and the socio-rherorical strategy of Hebrews. Trinity Journal, 21 No 1, Spr 2000, p. 25-43

4. Бленд, А. Комментарий на Послание к Евреям, 2019. URL: http://www.alexblend.net/ ?cat $=41$.

5. Толковая Библия или комментарий на все книги Священного Писания Ветхого и Нового Завета. Т.3. (1911-1913). Издание преемников Лопухина А.П. Второе издание института перевода Библии. Стокгольм, 1987.

6. Мак-Дональд У. Библейский Комментарий для Христиан. Новый Завет. CLV. Christiche Literatur-Verbreitung e.V. Postfach Bielefed, 2000.

7. Уирсби У. Будь уверенным. Чикаго. SGP. 1990.

8. Гудинг Д. Осуществление Ожидаемого. / Пер. с англ. World Wide Printing. Duncanville, USA, 1988

9. Новый Библейский Комментарий: В 3 ч. Ч. 3. Новый Завет. / Пер. с англ. Санкт-Петербург : Мирт, 2001. 751 с.

10. Толкование новозаветных посланий и книги Откровения. / Гл. редактор Платон Харчлаа, Изд. РЕИ и СМИ, 1990, 593 с.

11. Гандри Р. Обзор Нового Завета. / Пер. с англ. Санкт-Петербург : Христианское общество «Библия для всех», 2001. 493 с.

12. Гатри Д. Введение в Новый Завет. / пер. с англ. Одесса : «Богомыслие», 1996. 800 с.

13. Тенни М. Мир Нового Завета. International Correspondence Institute. Belgium Biblical Public 1990.

14. Lawrence Richard O. The Bible Reader's Companion. Victor Books. A Division of Scripture Press Publication Inc., USA, Canada, England, 1991.

15. Whitfield Bryan J. The Three Joshuas of Hebrews 3 and 4. Perspectives in Religious Studies, 37 No 1ю Spr 2010, p. 21-35.

16. Клеон Л. Роджерс-младший. Клеон Л. Роджерс III. Новый Лингвистический и экзегетический ключ к греческому тексту Нового Завета / Пер. с англ. Санкт-Петербург : Христианское общество «Библия для всех», 2001. 


\title{
БІБЛІЙНА КОНЦЕПЦІЯ БОЖОГО СПОКОЮ В СВІТЛІ ПОСЛАННЯ ДО ЄВРЕЇВ
}

\author{
Олександр Шумілін \\ Бішкекський біблійний коледж \\ вул. Тверська, 42, 720080, м. Бішкек, Киргизстан
}

Стаття присвячена дослідженню богословської концепції Божого спокою в контексті 3-4 глав Послання до євреїв. Мета - показати, яке значення автор послання вкладає в це поняття, а також зрозуміти: чому автор торкається цієї теми і як ця концепція вписується в контекст всього Послання, а також всієї Біблії. Особливу увагу приділено дослідженню ключової фрази «Давайте працювати, щоб увійти у спокій Божий».

Проведено аналіз джерел, присвячених цій темі. Показано, що $є$ різні думки щодо «спокою». Одні автори стверджують, що Божий спокій пов'язаний з есхатологічними подіями і знаходиться після завершення життєвого шляху християнина на небі. Інші вважають, що спокій - це повернення втраченого єднання людини з Богом, це спокій в Бозі, дарований нам через Христа. Треті вважають, що спокій - це свідчення нашого сумління про прощення гріхів і спокій у домі Отця на Небесах. Четверті бачать у спокої поєднання спасіння у Христі (впевненість у спасінні) з майбутнім спокоєм у небесах. П'яті бачать спокій у Христі, а його втрату як результат сумнівів віруючих. Чим викликано різне розуміння Божого спокою? Чи є інші можливі тлумачення? Відповісти на ці питання - одне із завдань цього дослідження.

Для дослідження в рамках цієї статті використаний герменевтико-екзегетичний метод. Зроблено короткий вступ у Послання, наведена приблизна дата написання Послання, визначені головна тема і цілі послання, зазначений історичний контекст. Проведено етимологічний аналіз слів і літературний аналіз тексту. Показано, як автор Послання використовує типологію в досягненні поставленої ним мети.

Показано, що послання в стилі проповіді було написано або в період гонінь на християн, або в період, що передує цьому часу. Можливо, важкі часи вплинули на віру членів громади. Деякі 3 них збайдужіли, деякі відпали, деякі впали в гріх, деякі, можливо, знову повернулися до іудейської системи цінностей. У Посланні автор намагається знову звернути увагу членів громади на Христа. Він показує Його перевагу над пророками, Ангелами, Авраамом, Мойсеєм, Аароном, старозавітної священицької системи служіння. Автор показує божественність Ісуса Христа, говорить про безцільність, безглуздість і навіть загрози життю без Нього і закликає повернутися до віри в Нього.

У своєму герменевтико-екзегетичному дослідженні старозавітних оповідань про спокій у Пс.95:8-11 і Бут.2:2 автор Послання показує, що істинний Божий спокій для віруючих усіх часів це навіть не обітована земля і захист від ворогів, а відновлення порушених взаємин з Богом, єднання з Ним і перебування у Христі. Зрештою, спокій - це вічне спілкування з Богом у Небесному Царстві.

Тема Божого спокою актуальна і в наш час, має велике значення для всіх християн і особливо для тих, хто перебуває в гоніннях, труднощах, а також тих, хто духовно ослаб, охолов і знаходиться в небезпеці відпадіння від Христа.

Ключові слова: Божий спокій у Посланні до Євреїв, Послання до Євреїв 3-4, попередження про відпадіння в посланні до Свреїв, увійти в спокій Божий. 